\title{
Personifikasi dan Simile dalam Prosa Lirik Pengakuan PARIYEM KARYA Linus Suryadi A.G.
}

\author{
Mujid Farihul Amin dan Ary Setyadi \\ Fakultas Ilmu Budaya, Universitas Diponegoro \\ moejid70@gmail.com dan arysetyadi58@gmail.com
}

\begin{abstract}
This research is aimed to know the function of personification and simile in lyrical prose Pengakuan Pariyem. The method used in this research is the common method used in stylistics. Conclusion: personification indicates that it function is to describe real and living atmosphere, enabling to create both image and aesthetic of the speech. Simile, does not only indicate its function as aesthetic maker, but also to create image itself contextually.
\end{abstract}

Key words: Stylistica, language style, personification, simile.

\section{Intisari}

Penelitian ini bertujuan untuk mengetahui fungsi gaya personifikasi dan simile dalam prosa lirik Pengakuan Pariyem. Metode yang digunakan dalam penelitian ini adalah metode yang lazim digunakan dalam stilistika. Simpulan yang diperoleh: gaya bahasa personifikasi menampakkan fungsi mampu menggambar-kan suasana seakan hidup dan nyata, sehingga mampu membangkitkan suasana, kesan/citraan terhadap indera tertentu; sekaligus mampu menciptakan keindahan (estetika) tuturan itu sendiri. Gaya bahasa simile, di samping menampakkan fungsi sebagai pencipta unsur keindahan (estetika), ternyata kehadirannya sanggup juga menciptakan kesan atau citraan tersendiri (secara kontekstual).

Kata-kata Kunci: Stilistika, gaya bahasa, personifikasi, simile

\section{Pendahuluan}

Karya sastra dapat dibedakan menjadi tiga genre, yaitu 1. prosa, 2. puisi, dan 3. drama. Dalam genre prosa dikenal adanya bentuk prosa lirik, yaitu sebuah gubahan yang berbentuk prosa tetapi pekat bahasanya seperti puisi. Pembeberan pikiran dan perasaan dibuat secara singkat, tepat, sebab merupakan curahan (isi) hati pengarang. Sebagaimana dikatakan oleh Hartoko (1986) prosa lirik atau 
lirikal adalah prosa yang diperkaya dengan gaya lirik, seperti irama, simbolik bunyi, metafora sebagi sarana penyampaian perasaan batin pengarang.

Sejalan dengan pendapat di atas, sebuah karya sastra yang berjudul Pengakuan Pariyem buah karya Linus Suryadi AG merupakan contoh karya sastra yang tergolong dalam genre prosa lirik. Sebab dalam karya sastra tersebut menampakkan ciri-ciri sebagaimana pendapat Hartoko yang dikutip tersebut.

Berdasarkan strukturnya, prosa lirik menampakkan unsur-unsur yang terdapat, baik dalam prosa maupun puisi. Unsur-unsur struktur prosa, seperti: tema, latar, tokoh, pusat pengisahan, dan pemakaian bahasa dan gaya bahasa juga dapat dijumpai di dalamnya. Demikian pula unsur-unsur puisi, seperti : permainan bunyi, persajakan dan irama, dan penggunaan bahasa dan bait-bait juga ditampakkan. Dengan demikian unsur intrinsik kedua genre tersebut dapat ditemui juga dalam karya sastra yang berbentuk prosa lirik.

Berdasarkan sajian paparan tentang pengertian dan struktur prosa lirik di atas, maka sangat beralasan apabila keberadaan prosa lirik perlu dikaji dengan memanfaatkan (ilmu) stilistika. Sebab apa yang disebut (ilmu) stilistika adalah kajian terhadap karya sastra yang berpusat pada pemakaian bahasa (Atmazaki, 1990). Keberadaan (ilmu) stilistika termasuk dalam bidang interdisipliner, yaitu antara (ilmu) linguistik dengan (ilmu) kesusastraan, sebab (ilmu) stilistika mengkaji bahasa yang dipakai dalam karya sastra (Kentjono (Ed.),1982).

\section{Rumusan Masalah}

Karya sastra yang berjudul Pengakuan Pariyem karangan Linus Suryadi AG, sebagaiamana telah disebut di depan menampakkan ciri sebagaimana yang dimiliki baik, dalam prosa maupun dalam puisi, khususnya dalam hal pemakaian gaya bahasanya. Oleh sebab itu, upaya pengkajian permasalahan berfokus pada persoalan pemakaian gaya bahasa personifikasi dan simile dalam karya sastra Pengakuan Pariyem serta fungsi atau manfaatnya.

Telah disinggung di atas, bahwa genre karya sastra dapat dibedakan menjadi tiga, yaitu 1) prosa, 2) puisi, dan 3) drama. Dalam genre prosa dikenal juga apa yang disebut dengan prosa lirik. Dikatakan prosa lirik sebab karya sastra yang 
bersangkutan menampakkan ciri sebagaimana yang dimiliki oleh genre, baik prosa maupun puisi.

Banyak buku kesusastraan Indonesia yang membicarakan prosa lirik, misalnya Hartoko (1986) mengatakan bahwa prosa lirik atau lirikal adalah prosa yang diperkaya dengan gaya lirik, seperti irama simbolik bunyi, metafora sebagai sarana penyampaian perasaan batin pengarang. Suwandi dan Mashari (1978) mengatakan bahwa prosa lirik merupakan karangan yang mempunyai bentuk perpaduan antara prosa dan puisi, yaitu karya sastra berupa prosa yang di dalamnya mengandung unsur-unsur ciri puisi atau sebaliknya. Semi (1988) mengatakan bahwa prosa lirik dilihat berdasarkan strukturnya tampak sebagaimana struktur unsur-unsur prosa dan puisi, yaitu susunan baris-baris yang disususn sedemikian rupa sehingga antara bagian yang satu dengan bagian yang lain tersusun dan terkait secara baik. Teeuw (1983) mengatakan bahwa unsur-unsur intrinsik yang ada saling mengikat antara satu dengan yang lain dalam keselarasan sehingga membentuk makna cerita yang terlepas dari pengarangnya.

Bertolak dari sajian pendapat di atas, maka tampak dengan jelas bahwa prosa lirik merupakan suatu genre karya sastra yang menarik, sebab menampakkan ciri sebagaimana yang dimiliki oleh baik prosa maupun puisi. Oleh sebab itu, keberadaan prosa menarik pula apabila dijadikan satu bahan kajian tersendiri. Khususnya prosa lirik yang berjudul Pengakuan Pariyem karangan Linus Suryadi AG.

Menyimak beberapa sumber acuan yang secara khusus membicarakan prosa lirik Pengakuan Pariyem tersebut, tampak dengan jelas bahwa persoalan upaya ke arah kajian yang relatif memadai belum pernah dilaksanakan; terlebih-lebih kajian yang didasarkan pada (ilmu) stilistika, khususnya yang berfokus pada pendeskripsian gaya bahasa personifikasi dan simile.

Pengertian gaya bahasa relatif banyak dijumpai dalam buku yang membicarakan, baik (teori) bahasa maupun (teori) sastra, di bawah ini disajikan beberapa pendapat para pakar. 
Slametmulyana (dalam Pradopo, 1993) mendefinisikan gaya bahasa sebagai susunan perkataan yang terjadi akibat perasaan hati seorang pengarang, baik disengaja maupun tidak sanggup memberikan perasaan tersendiri bagi pembaca. Demikian pula pendapat Abrams (dalam Prodopo, 1993), "Gaya bahasa merupakan ekspresi bahasa seseorang dalam prosa atau cerita, bagaimana berbicara atau berkata yang ingin dikatakan."

Mangunsubroto (1953) menjelaskan, gaya bahasa adalah susunan kata yang mempunyai kekuatan istimewa. Dikatakan demikian, sebab kehadiran gaya bahasa mempunyai kekuatan tersendiri sebagai sebuah ucapan/kalimat karena mengacu pada arti yang bersifat majas.

Soedibyanto (1955) mengenai gaya bahasa berpendapat, bahwa gaya bahasa adalah alat yang utama bagi seorang pengarang atau pujangga guna melukiskan suatu pikiran atau pendapat dalam dunia sastra. Pelukisan dengan gaya bahasa yang dimaksud berlaku wajar, sebab cerita dalam dunai sastra merupakan hasil imajinasi.

Jassin (1965) mengenai gaya bahasa berpendapat, bahwa gaya bahasa merupakan segala cara seorang pengarang dalam melukiskan sesuatu demi efek tertentu, sebab kehadiran gaya bahasa dapat membantu secara jelas apa yang menjadi buah pikiran pengarang (karya sastra). Salah satu efek tertentu yang hendak dicapai melalui gaya bahasa adalah agar pembaca dengan kemampuan daya responsinya dapat menemukan arti yang dimaksud secara luas. Pendapat Jassin tersebut sejalan dengan pendapat Hutagalung (1971) yang mengatakan, "Cara pemakaian bahasa oleh seorang pengarang untuk mencapai efek tertentu dalam karyanya."

Pradopo, dkk. (1978) berpendapat bahwa gaya bahasa ialah sarana untuk berpikir, sehingga orang lain (pembaca) lebih dapat menghayati gagasan yang dipaparkan sebagai gambaran perasaan pengarang. Pendapat Prodopo, dkk. tersebut sejalan dengan pendapat Sudjiman (1993) yang mengatakan bahwa gaya bahasa yang digunakan seorang pembicara/penulis berkait dengan cara penyampaian gagasan demi efek tertentu. Demikian pula pendapat Hartoko dan B. 
Rahmanto (1986) yang mengatakan, bahwa gaya bahasa adalah cara khas yang dipakai seseorang untuk pengungkapan diri (gaya pribadi).

Kridalaksana (1982) mengenai gaya bahasa berpendapat, gaya bahasa adalah pemanfaatan atas kekayaan bahasa oleh seseorang dalam bertutur atau meulis. Secara lebih khusus, pengertian gaya bahasa merupakan pemakaian ragam bahasa tertentu untuk memperoleh efek-efek tertentu; dan pengertian secara luas, bahwa gaya bahasa merupakan keseluruhan ciri-ciri bahasa sekelompok penulis sastra.

Pengertian gaya bahasa juga dikemukakan oleh Keraf (1984) yaitu, istilah gaya bahasa merupakan bentuk frasa yang terdiri atas kata gaya dan bahasa. Kata gaya diberikan batasan sebagai cara mengungkapkan diri sendiri, baik melalui bahasa, tingkah laku, cara berpakaian, dan sebagainya. Sedangkan apabila dilihat dari segi bahasa, batasan gaya bahasa adalah cara menggunakan bahasa; yaitu cara mengungkapkan apa yang ada dalam jiwa dan pikiran penyair melalui bahasa secara khas untuk menimbulkan efek bahasa tertentu. Sajian pendapat tentang gaya bahasa yang bersumber dari Keraf (1984) ini relatif lebih luas, sebab telah juga disinggung macam-macam gaya bahasa; dan akibat dari telah disinggung macam-macam gaya bahasa, maka macam-macam gaya bahasa yang ada akhirnya dijadikan acuan analisis data selanjutnya dalam pelaksanaan penelitian ini.

Sajian bahasa mengenai macam gaya bahasa, mengacu pada pendapat Keraf dalam buku yang berjudul Diksi dan Gaya Bahasa (1984). Sebab, dari sekian buku yang dijadikan acuan dalam pelaksanaan penelitian ini, hanya pendapat Keraf (1984) yang relatif luas; sehingga sewaktu dibahas macam gaya bahasa mengacu pada pendapat yang dimaksud.

Macam gaya bahasa berdasarkan langsung-tidaknya makna menurut Keraf (1984) mencakup: a. gaya bahasa berunsur pemanfaatan personifikasi; b. gaya bahasa berunsur pemanfaatan simile atau persamaan; c. gaya bahasa berunsur pemanfaatan metafora; d. gaya bahasa berunsur pemanfaatan sinekdoke; e. gaya bahasa berunsur pemanfaatan hiperbola; dan $\mathrm{f}$. gaya bahasa berunsur pemanfaatan eufemisme. 
Macam dan fungsi gaya bahasa yang dibahas dalam artikel ini dibatasi hanya pada gaya bahasa personifikasi dan simile.

Tujuan yang hendak dicapai dalam penelitian ini, adalah :

memberi gambaran bahwa pengertian keindahan dalam karya sastra tidak semata-mata akibat adanya kebulatan jalinan sebuah unsur intrinsik yang hanya meliputi : isi cerita, alur, tokoh, setting, dan pusat pengisahan saja, akan tetapi masalah penggunaan bahasa, khususnya gaya bahasa personifikasi dan simile, juga sangat berperan dan memberi gambaran bahwa kehadiran gaya bahasa personifikasi dan simile dalam karya sastra tidak hanya berlaku sebagai alat penambah keindahan saja, akan tetapi ternyata kehadirannya dapat difungsikan untuk tujuan-tujuan tertentu.

Kontribusi yang dapat dikedepankan sehubungan dengan rencana pelaksanaan penelitian ini adalah : berorientasi pada perlunya pengembangan ilmu pengetahuan, khususnya dalam hal (peng)kajian karya sastra dengan memanfaatkan kelebihan (ilmu) stilistika, sebab keberadaan (ilmu) stilistika merupakan interdisipliner, yaitu melibatkan kelebihan (ilmu) bahasa dan (ilmu) sastra.

\section{Metode Penelitian}

Metode yang dipakai dalam rencana pelaksanaan penelitian ini mencakup dua metode secara secara sekaligus, yaitu 1. Pemanfaatan metode yang berlaku dalam dunia (ilmu) bahasa dan (ilmu) sastra, dan 2. Pemanfaatan metode yang belaku dalam bidang (ilmu) stilistika.

Metode yang dapat dimanfaatkan sehubungan dengan penerapan teori struktural kedua teori tersebut adalah :

a. Untuk penerapan teori struktural bahasa dipergunakan metode distribusional, yaitu dengan memperhatikan penilaiaan struktur intern hubungan antarunsur dalam satu kata; 
b. Untuk penerapan teori struktural sastra dipergunakan metode unsur intrinsik, yaitu dengan memeperhatikan unsur jalinan intrinsik pembentuk karya sastra.

Pedoman pokok yang mendasari rencana pelaksanaan penelitian ini bertumpu pada pemanfaatan ketiga tahapan strategis penelitian, yaitu 1 . Pelaksanaan strategis pengumpulan data, 2. Pelaksanaan strategis klasifikasi data, dan 3. Pelaksanaan strategis analisis dan pemaparan data (Sudaryanto, 1985).

\section{Hasil dan Pembahasan}

\section{Gaya Bahasa Berunsur Pemanfaatan Personifikasi}

Pengertian personifikasi berdasarkan beberapa sumber acuan di katakan,1. "Gaya bahasa perbandingan yang membandingkan benda mati atau tidak dapat bergerak seolah-olah bernyawa dan dapat berperilaku seperti manusia." (Sudaryanto, 1983); 2. "Pengumpamaan (pelambangan) benda mati sebagai orang atau manusia, .." (Kamus Besar Bahasa Indonesia, 2001); 3. "Majas dalam bahasa yang mengumpamakan benda-benda mati seperti manusia atau binatang yang dapat berbuat sesuatu, ..." (Badudu, 2003); dan 4. personifikasi dikatakan pula sebagai pemberian sifat-sifat atau ciri-ciri manusia pada benda-benda mati, binatang, atau pun suatu ide (Keraf, 1984; Suminto, 1985).

Bertolak dari beberapa pendapat tentang pengertian gaya bahasa personifikasi tersebut, maka dapat disimpulkan bahwa personifikasi adalah: peminjaman sifat atau ciri benda mati berumpamakan memiliki sifat atau ciri makhluk hidup. Dengan demikian pemanfaatan gaya bahasa personifikasi ini berupaya mengintensifkan pernyataan yang bertujuan untuk membangkitkan warna emosi benda mati yang dapat bergerak sebagaimana makhluk hidup (layaknya seorang manusia, binatang). Contoh:

(9) Angin segar pun berkelakar

Diam-diam menyentuh panca indera

Dan burung-burung mengelepar

Terbang bebas di alam terbuka

(Halaman: 43) 
(10) Angin siang hari semilir

Mengusap wajah pohon-pohonan

Mampir ke jendela masuk ruang

(Halaman: 62)

Berdasarkan kedua data di atas tampak dengan jelas bahwa kehadiran kata berkelakar, menyentuh; mengusap wajah, dan mampir merupakan bukti adanya pemakaian gaya bahasa personifikasi; sehingga apa pun benda mati apabila dipinjami sifat dan ciri makhluk hidup, kepadanya seolah berperilaku sebagaimana makhluk hidup.

Kehadiran kata berkelakar pada data (9) memberi kesan citraan bahwa 'angin seolah mempunyai kekuatan daya emosi sebagaimana makhluk hidup (manusia, binatang), sehingga sifat dan ciri mampu atau dapat berkelakar pada makhluk hidup dipinjamkan pada angin'.

Kehadiran kata menyentuh pada data (9) memberi kesan citraan bahwa ‘angin seolah mempunyai kekuatan daya emosi sebagaimana makhluk hidup (manusia, binatang) yang beranggota badan tangan, sehingga sifat dan ciri tangan yang dimiliki oleh manusia, binatang, juga dimiliki oleh angin yang pada gilirannya mampu menyentuh sesuatu`.

Kehadiran kelompok kata mengusap wajah pada data (10) memberi kesan citraan bahwa `angin seolah mempunyai kekuatan daya emosi sebagaimana makhluk hidup (manusia, binatang) yang beranggota badan tangan, sehingga sifat dan ciri tangan yang dimiliki oleh manusia, binatang`; demikian pula 'pohon-pohonan seolah makhluk hidup yang memiliki wajah, yang layak diusap setiap saat', akhirnya juga dimiliki oleh angin sehingga mampu berbuat mengusap wajah yang dimiliki oleh pohon-pohonan.

Kehadiran kata mampir pada data (10) memberi kesan citraan bahwa ‘angin seolah mempunyai kekuatan daya emosi sebagaimana makhluk hidup (manusia, binatang) yang beranggota badan kaki, sehingga sifat dan ciri kaki yang dimiliki oleh manusia, binatang, yang berfungsi sebagai alat dipakai menuju ke tempat untuk (sekedar) mampir'. 
Bertolak dari kedua data di atas tampak jelas bahwa yang dipinjami sifat dan ciri milik makhluk hidup (sebagaimana manusia, binatang) adalah benda mati yang disebut dengan nama angin yang mampu `melakukan sesuatu (berkelakar, menyentuh, dan mengusap wajah) sebagaimana makhluk hidup`, dan pepohonan yang digambarkan `memiliki wajah sebagaimana makhluk hidup yang diusap oleh datangnya angin semilir`.

Bukti bahwa kehadiran kata/kelompok kata berkelakar, menyentuh, mengusap wajah, dan mampir berfungsi sebagai pencipta unsur keindahaan (estetika), dan sekaligus mampu memberikan kesan/citraan yang bersifat majas, kedua data di atas sangat berbeda apabila diubah menjadi (9a, 10a) yang bersifat lugas berunsur kata/kelompok kata: bertiup, mengenai, terasa, mengenai ranting, berembus.

(9a) Angin segar pun bertiup

Diam-diam terasa oleh panca indera

Dan burung-burung mengelepar

Terbang bebas di alam terbuka.

(10a) Angin siang hari semilir mengenai ranting pohon-pohonan berembus ke jendela masuk ruangan.

Contoh lain pemakaian gaya bahasa personifikasi

(11) Sekali bergerak lemah gemulai laksana daun nyiur melambai Apalagi, bila njoget bedhoyo Alangkah nletheng dia - santai Laksana aliran sungai

(Halaman: 123).

Data (11) secara jelas nyata daun nyiur diumpamakan sebagai makhluk hidup (khususnya manusia) mempunyai kemampuan 'melambaikan tangan', sehingga kehadirannya mampu memberikan unsur keindahan (estetika), dan kesan 
citraan yang mampu menggambarkan konteks atas gambaran 'betapa lembut gemulainya setiap gerakan yang diperagakan oleh para penari yang bersangkutan`.

Kehadiran gaya bahasa personifikasi sebagaimana ketiga data di atas berfungsi sebagai pencipta unsur keindahan (estetika), sekaligus mampu memberikan gambaran konteks atas lirik/teks itu sendiri, yaitu bahwa pihak pembaca terlibat dan terbawa dalam situasi latar yang sedang terjadi. Suasana saat itu dapat dibayangkan begitu indah, menyenangkan, dan romantis. Dengan kata lain, kehadiran gaya bahasa personifikasi semacam ketiga data di atas secara jelas menampakkan fungsi `mampu menggambarkan suasana seakan hidup dan nyata, sehingga mampu membangkitkan suasana, kesan/citraan terhadap indera tertentu; sekaligus mampu menciptakan keindahan (estetika) tuturan itu sendiri.

\section{Gaya Bahasa Berunsur Pemanfaatan Simile/Persamaan}

Gaya bahasa simile atau dalam bahasa Indonesia disebut dengan `persamaan, perbandingan, atau perumpamaan`, berdasarkan data yang ada dalam prosa lirik Pengakuan Pariyem relatif paling banyak ditemukan. Sebab, pemakaian gaya bahasa simile secara teks dan konteks seiring dengan latar penokohan atas tokoh sentral/utama yang berstatus sebagai pembantu rumah tangga (PRT) yang bernama Pariyem.

Tokoh sentral/utama Pariyem saat berkesempatan bermain cinta dengan salah satu anggota tuan rumah mampu melambungkan lamunan dan angan-angannya sebagaimana dunia nyata penghuni rumah yang dilayaninya. Cinta yang sedang melanda mampu membawa Pariyem ke dunia imajinasinya, sehingga dirinya berlaku sama sebagaimana makna kata yang secara eksplisit mampu menunjukkan persamaan: seperti ..., bagai ..., laksana ...," (Kamus Besar Bahasa Indonesia, 2001).

Pengertian gaya bahasa simile/persamaan berdasarkan sumber acuan dikatakan, 1. "Umpama; majas perbandingan yang menggunakan kata pembanding, misalnya: seperti, sebagai, bak, bagai, bagaikan, laksana, umpama." (Badudu, 2003); 2. "Majas pertautan yang membandingkan dua hal yang secara hakiki berbeda, tetapi dianggap mengandung segi yang serupa; 
dinyatakan secara eksplisit dengan kata: seperti, bagai, laksana (Kamus Besar Bahasa Indonesia, 2003).

Mendasarkan pada dua kutipan di atas, maka pengertian gaya bahasa simile dapat dikatakan: pemakaian makna kata secara majas demi membandingkan "sesuatu" seolah berlaku sama, yang secara eksplisit dinyatakan dengan kata: seperti, sebagai, bak, bagai, bagaikan, laksana, umpama, dan semacamnya. Contoh data pemakaian gaya bahasa simile dalam prosa lirik Pengakuan Pariyem sebagaimana dapat dilihat sajian berikut.

Berdasarkan data yang dapat dikumpulkan, fakta pemakaian gaya bahasa simile dalam Pengakuan Pariyem menggunakan kata persamaan: ibarat, bagaikan, sebagai, kayak, bak, laksana, dan kata-kata pembanding lainnya.

Contoh data pemakaian gaya bahasa simile yang berunsur kata ibarat:

(12) Antara tresna dan pengakuan

hakekatnya satu kebulatan

ibarat kambing dengan rumput.

(Halaman: 122)

(13)

Ibarat kere munggah bale

(Halaman 156)

Contoh data pemakaian gaya bahasa simile yang berunsur kata laksana,

(14) Alangkah mengagumkan dia!

Lha, pinggulnya megal-megol

Laksana mentok berjalan

Sekali dia jingkrak-jingkrak

laksana orang kesurupan.

Sekali bergerak lemah gemulai

laksana daun nyiur melambai

Apalagi, bila njoget bedhaya

Alangkah nletheng dia - santai - 
Laksana aliran sungai.

(Halaman: 122-123)

Contoh data pemakaian gaya bahasa simile yang berunsur kata kayak, layak.

(15) Saya raba dadanya dheg-dhegan, lho napasnya tak karuan

Dalam gelora hidup berdegup

Kayak sepur grenjeng berjalan

Saya lemas tapi campur gemes

(Halaman 75).

(16) Ah, ya, nDoro Wiwit

Dia punya katuranggan Dewi Wara Srikandi

Tubuhnya langsing dan kulitnya langsat

Matanya blalak-blalak alias cemerlang

Tangannya, layak gandhewa pinenthang

dan pinggulnya, wadhuh layak nampan

Bila berjalan kayak macan lapar

-lengket-lengket.

(Halaman 109)

Contoh data pemakaian gaya bahasa simile berunsur kata: bagaikan, sebagai:

(17) Ibarat idu geni, kata-katanya masah bagaikan wisa ular weling di sungai

(Halaman: 53).

(18)

Dan saya hanya bisa kethap-kethip 
bagaikan kera kena tulup pemburu

(Halaman: 147).

(19) $\ldots$

Dia titis menangkap makna jagongan

sebagai pemburu menembak kijang di hutan

selalu tepat, sekali bidik kena sasaran

(Halaman: 34)

Kehadiran kata ibarat, laksana, kayak, layak, bagaikan, dan sebagai dalam data (12-19) sebagai penanda gaya bahasa simile, di samping menampakkan fungsi sebagai pencipta unsur keindahan (estetika), ternyata kehadirannya sanggup juga menciptakan kesan atau citraan tersendiri (secara kontekstual). Dengan demikian, kehadiran beberapa kata (sebagai penanda ciri gaya bahasa simile) tersebut akhirnya sanggup memberikan ciri penggunaan bahasa dalam (karya) sastra, sebab beberapa kata tersebut mengacu pada makna kata yang bersifat majas.

Akibat kehadiran beberapa kata tersebut yang berfungsi sebagai pencipta unsur keindahan (estetika), pencipta kesan atau citraan, dan pemberi ciri penggunaan bahasa dalam (karya) sastra, sehingga apabila kata yang berperan sebagai penanda makna majas pada data $(12$ - 19) dilesapkan, maka persoalan indah (estetis), kesan citraan, dan ciri bahasa sastra tidak akan tampak lagi; sebagaimana tampak pada sampel data (12a, 14a, 16a, 18a) berikut.

(12a) Antara tresna dan pengakuan hakekatnya satu kebulatan (...) kambing dengan rumput.

(14a) Alangkah mengagumkan dia! Lha, pinggulnya megal-megol (...) mentok berjalan

(16a) $\quad \ldots$ matanya blalak-blalak alias cemerlang 
Tangannya, (...) gandhewa penenthang

dan pinggulnya, waduh (...) nampan

Bila berjalan (...) macan lapar

- lengket-lengket.

(18a) $\quad \cdots$

Dan saya hanya bisa kethap-kethip

(...) kera kena tulup pemburu.

Berdasarkan data (12a, 14a, 16a, dan 18a) di atas tampak dengan jelas bahwa ketiga data yang bersangkutan tidak lagi mengandung unsur indah (estetik) maupun kesan atau citraan yang mampu menggambarkan konteks yang menyertainya. Adapun faktor penyebab utamanya adalah akibat dilesapkannya kata ciri penanda gaya bahasa simile itu sendiri, yaitu dilesapkannya kata ibarat, layak, sebagai, dan bagaikan dari lirik yang bersangkutan.

\section{Simpulan}

Berdasarkan hasil dan pembahasan, maka dapat diambil simpulan sebagai berikut:

a. Pemakaian gaya bahasa personifikasi bertujuan untuk membangkitkan warna emosi benda mati yang dapat bergerak sebagaimana makhluk hidup (layaknya seorang manusia, binatang).

b. Gaya bahasa personifikasi menampakkan fungsi 'mampu menggambarkan suasana seakan hidup dan nyata, sehingga mampu membangkitkan suasana, kesan/citraan terhadap indera tertentu; sekaligus mampu menciptakan keindahan (estetika) tuturan itu sendiri '

c. Gaya bahasa simile dapat didefinisikan: pemakaian makna kata secara majas demi membandingkan "sesuatu" seolah berlaku sama, yang secara eksplisit dinyatakan dengan kata: seperti, sebagai, bak, bagai, bagaikan, laksana, umpama, dan semacamnya.

d. Gaya bahasa simile, di samping menampakkan fungsi sebagai pencipta unsur keindahan (estetika), ternyata kehadirannya sanggup juga menciptakan kesan atau citraan tersendiri (secara kontekstual). 


\section{Daftar Pustaka}

Atmazaki. 1990. Ilmu Sastra Teori dan Terapan. Padang: Angkasa Raya.

Badudu, J.S. 2003. Kamus Kata-kata Serapan Asing dalam Bahasa Indonesia. Jakarta: Penerbit Buku Kompas.

Hartoko, Dick dan B. Rahmanto. 1986. Pemandu di Dunia Sastra. Yogyakarta: Yayasan Kanisius.

Hutagalung, M.S. 1971. Memahami dan Menikmati Puisi. Jakarta: Badan Penerbit Kristen.

Jassin, H.B. 1965. Tifa Penyair dan Daerahnya. Jakarta: Gunung Agung. Kamus Besar Bahasa Indonesia. 2001. Jakarta Gramedia.

Kentjono, Djoko (Ed). 1982. Dasar-dasar Linguistik Umum. Jakarta: Fak. Sastra Universitas Indonesia.

Keraf, Gorys. 1984. Diksi dan Gaya Bahasa. Jakarta: Gramedia.

Kridalaksana, Harimurti. 1982. Kamus Linguistik. Jakarta: Gramedia.

Mangunsubroto, F.M. 1953. Ikhtisar Kesusasteraan Indonesia. Jogjakarta: UPP Prapancha.

Pradopo, Rachmad Djoko, dkk. 1978. Memahami Sajak-sajak Soebagio Sastrowardoyo. Yogyakarta: Fak. Sastra dan Kebudayaan UGM.

Pradopo, Rachmad Djoko. 1993. Pengkajian Puisi. Yogyakarta: Gadjah Mada University Press.

Semi, Atar. 1988. Anatomi Sastra. Padang: Angkasa Raya.

Soedibyanto, Emmanuel. 1955. Sari Sastra dan Gaya Bahasa Indonesia. Malang: Taman Sari.

Sudjiman, Panuti (Ed). 1993. Bunga Rampai Stilistika. Jakarta: Pustaka Utama Graffiti.

Sudaryanto. 1985. Aneka Teknik dalam Menangani Penelitian Bahasa. Yogyakarta: MLI.

Suminto. 1985. Pelajaran Kesusasteraan Indonesia. Surakarta: Obor Mas.

Suryadi AG, Linus. 1980. Pengakuan Pariyem. Jakarta: Pustaka jaya.

Suwandi dan Mashari. 1987. Kesusasteraan Indonesia. Surabaya: Warga.

Teeuw, A. 1983. Membaca dan Menilai Sastra. Jakarta: Gramedia. 